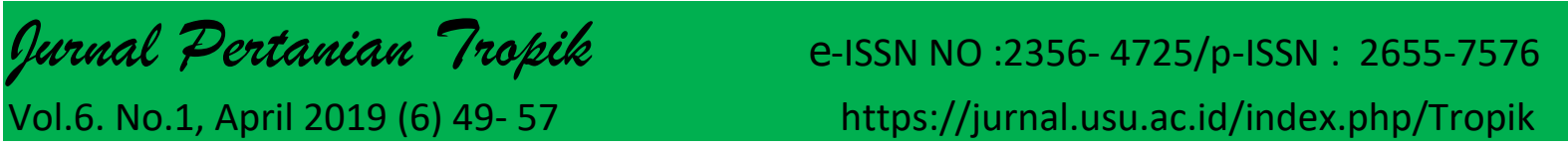

\title{
Efek Penyimpanan Secara Kriopreservasi Pada Jenis dan Lama Perendaman Kriopektan Dengan Perbedaan Kondisi Biji Terhadap Pertumbuhan Benih Manggis (Garcinia mangostana $\mathrm{L}$ )
}

Effects of Storage by Cryopreservation on Types and Duration of Cryopectant Soaking With Different Conditions of Seeds on the Growth of Mangosteen Seeds (Garcinia mangostana L)

\section{Dede Suhendra}

Sekolah Tinggi Ilmu Pertanian Labuhanbatu

Corresponding author : Dede_SuhendraSKB@yahoo.com

\section{ABSTRACT}

Effect Storage In Criopreservasi On Type And Old South Crioprotektan Different Conditions Of Seeds Against Growth of Mangosteen Seeds (Garcinia mangostana L). The aim of the study was to determine the type, duration of soaking and the different conditions of mangosteen seeds and their interaction with the growth of mangosteen seeds (Garcinia mangostana L). This research was carried out at the Laboratory of Applied Sciences in Seed Technology of Labuhanbatu College of Agricultural Sciences (STIPER), starting March to July 2018, using factorial randomized block design with 3 treatment factors namely cryoprotectant type, cryoprotectant immersion and mangosteen fruit flesh. Parameters observed were number of shoots (fruit), shoot height $(\mathrm{cm})$, root length $(\mathrm{cm})$, and sprout dry weight $(g)$. The results showed that the highest application of the parameters was the use of non-fruit flesh with cryoprotectant PVS2 and 180 minutes soaking time. The results of the research were used to develop mangosteen seed storage for the needs of the community, especially mangosteen farmers in Indonesia.

Keywords : mangosteen seeds, crioprotektan criopreservasi

\section{PENDAHULUAN}

Manggis (Garcinia mangostana L.) merupakan komoditas buah asli Indonesia yang mempunyai prospek sangat baik untuk dikembangkan. Manggis merupakan salah satu buah tropis yang sangat terkenal, dan disebut sebagai Queen of Fruits karena rasa buahnya yang lezat dan banyak digemari. Selain itu, manggis juga dimanfaatkan sebagai obat-obatan diantaranya sebagai anti inflamasi, anti bakteri dan sebagai perlakuan terhadap infeksi dan luka (Widiastuti et al., 2013).

Buah manggis merupakan salah satu komoditas ekspor unggulan dengan kontribusi sebesar 34,4\% dari total ekspor Indonesia. Pada tahun 2009 volume ekspornya sebesar 4.285 ton dengan nilai US\$ 2.781.712 lalu pada tahun 2010 mengalami peningkatan menjadi 8.225 ton dengan nilai US\$ 6.310.272 (Novita, 2011). Volume ekspor manggis Indonesia meningkat nyata pada dua bulan pertama tahun 2011, hampir sama dengan volume ekspor sepanjang tahun 2009 (Whidhiasih, 2012). Negara tujuan ekspor buah manggis adalah Cina, Jepang, Singapura, Hongkong dan sebagian negara timur tengah (Sumiasih, 2011).

Pada saat ini di beberapa daerah misalnya di Sumatera Utara, banyak ditemukan tanaman manggis yang sebagian besar telah berumur puluhan tahun dengan sedikit upaya pemeliharaan. Kondisi ini menyebabkan produktifitas manggis masih jauh di bawah potensi yang dimiliki. Peningkatan produksi dan kualitas buah manggis perlu dilakukan untuk memanfaatkan potensi dan peluang pasar yang terbuka. Peningkatan produksi 
manggis tersebut terus diupayakan. Salah satu dukungan teknologi budidaya yang efisien dan memadai diperlukan dimulai dari perbenihan (Ihsan dan Sukarmin, 2011). Salah satu upaya pengembangan manggis adalah dengan perbanyakan benih. Saat ini permasalahan yang dialami pada perbanyakan benih adalah dalam hal penyimpanan.

Koleksi plasma nutfah yang utama di dunia adalah berupa benih, karena menyimpan benih merupakan cara yang paling efisien untuk konservasi dalam jumlah besar. Dengan benih juga dapat memudahkan pendistribusian plasma nutfah. Kebutuhan dasar yang diperlukan dalam penyimpanan plasma nutfah ini adalah suhu serendah mungkin dan kadar air benih dalam keseimbangan dengan kelembaban relatif (Fitriyatmi, 1996).

Kriopreservasi merupakan teknik yang potensial untuk penyimpanan plasma nutfah jangka panjang dan juga teknik penyimpanan untuk jangka waktu yang lama. Dalam teknik ini sel-sel dan meristem ataupun bagian lain dari tanaman dibekukan dan disimpan pada kondisi yang terkontrol dalam nitrogen cair pada suhu $196^{\circ}$ C. Pada suhu nitrogen cair, sel-sel mempunyai sedikit atau bahkan sama sekali tidak mempunyai aktivitas metabolisme dengan viabilitas sel yang tetap terpelihara, sehingga bahan tanaman dapat disimpan dalam jangka waktu yang lama (Roostika, et al., 2004).

Faktor yang menentukan

keberhasilan kriopreservasi bergantung pada teknik yang diterapkan yakni pada teknik pembekuan cepat. Untuk teknik pratumbuh, keberhasilan ditentukan oleh jenis dan komposisi krioprotektan dalam media tumbuh. Untuk teknik vitrifikasi, enkapsulasi-vitrivikasi, dan droplet freezing, keberhasilan ditentukan oleh jenis, konsentrasi dan lama perendaman dalam krioprotektan (Windiastika, 2013).
Kondisi simpan merupakan salah satu faktor yang perlu diperhatikan, makin lama benih disimpan, kondisi lingkungan ruang penyimpanan memerlukan perhatian yang seksama. Kelembaban nisbi, suhu, dan komposisi udara yang ada pada ruang simpan akan mempengaruhi umur benih. Pada kondisi lingkungan penyimpanan dibedakan atas penyimpanan jangka pendek, menengah dan panjang pada benih ortodoks (Fitriyatmi, 1996).

\section{BAHAN DAN METODE}

Penelitian ini dilaksanakan di Laboratorium Ilmu Terapan Teknologi Benih Sekolah Tinggi Ilmu Pertanian (STIPER) Labuhanbatu, dimulai Maret sampai dengan Juli 2018.

Bahan yang digunakan dalam penelitian ini adalah benih manggis sebagai bahan pengamatan perkecambahan, nitrogen cair, DMSO, gliserol, etilen glikol, propilen glikol dan sukrosa sebagai krioprotektan, pasir, aquades dan air.

Alat yang digunakan dalam penelitian ini adalah tabung nitrogen, lemari pembeku (frezzer), bak kecambah, meteran, botol-botol plastik, gayung alumunium, timbangan analitik, beaker glass, batang pengaduk, oven, handsprayer, gunting, karung goni, label, ember, pisau, termometer, kalkulator, kamera dan alat tulis.

Menggunakan rancangan acak kelompok faktorial dengan 3 faktor perlakuan yakni jenis krioprotektan, lama perendaman krioprotektan dan daging buah manggis.

Pelaksanaan penelitian dilakukan dengan cara buah manggis dipanen pada perkebunan rakyat yang mana buah telah masak dengan ciri buah telah berwarna ungu kehitaman dengan kematangan dan bobot buah yang sama diambil dari pohon yang tumbuh lalu dibawa ke tempat penelitian untuk diambil bijinya. 


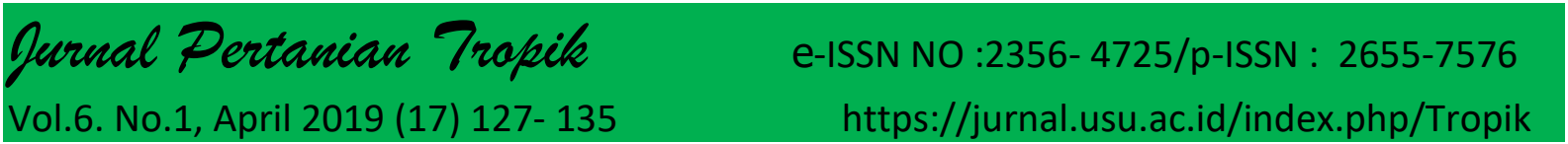

Setelah dilakukan pemanenan buah manggis dibersihkan lalu diambil biji vano ukurannya sama dengan cara buah dit 50 sehingga didapat bijinya yang tercupu dalam daging buah manggis yang berbentuk segmen-segmen berwarna putih yang mana di dalam buah manggis tersebut hanya terdapat 1-2 biji. Biji tersebut lalu dibersihkan dari daging buahnya dengan air dan abu sekam setelah bersih dilanjutkan dengan aplikasi perlakuan.

Sebelum aplikasi perlakuan dilakukan persiapan media perkecambahan yang digunakan adalah media pasir dengan ketebalan $\pm 4 \mathrm{~cm}$. Sebelum digunakan terlebih dahulu pasir disterilkan dengan cara digongseng selama 30 menit untuk menghilangkan kontaminasi dari cendawan dan bakteri.

Aplikasi perlakuan dilakukan dengan mempersiapkan benih yang akan dilakukan untuk pengujian adalah biji yang tidak rusak atau cacat fisik dan ukurannya benihnya besar. Benih yang sudah dipilih dilakukan aplikasi perlakuannya .Pelakuan tersebut dilakukan sebanyak 24 kombinasi perlakuan dan diulang sebanyak 3 kali.

Pengecambahan dilakukan pada bak perkecambahan benih dengan ukuran $30 \mathrm{~cm} \times 22 \mathrm{~cm} \times 4 \mathrm{~cm}$ sebanyak 20 benih per bak perkecambahan dengan kedalaman lobang tanam pada media pasir sebesar \pm 4 $\mathrm{cm}$.

Penyiraman dilakukan pada pagi dan sore hari dengan menggunakan handsprayer hingga media menjadi lembab dan dalam kondisi kapasitas lapang, dilakukan pemeliharaan setiap hari sampai 60 hari setelah ditanam pada bak perkecambahan.

Parameter yang diamati adalah tinggi tunas $(\mathrm{cm})$, jumlah tunas (buah), panjang akar $(\mathrm{cm})$ dan bobot kering kecambah $(\mathrm{g})$. Tabel 1 menunjukkan bahwa tinggi tunas tertinggi terdapat pada Jumlah Tunas (buah) perlakuan tanpa daging buah (D1) sebesar $9.20 \mathrm{~cm}$ dan terendah terdapat pada perlakuan daging buah (D2) sebesar 8.58 $\mathrm{cm}$.

\section{HASIL DAN PEMBAHASAN}

Tinggi Tunas $(\mathrm{cm})$

Tabel 1 menunjukkan bahwa tinggi tunas tertinggi terdapat pada perlakuan direndam selama 180 menit (L3) sebesar $9.55 \mathrm{~cm}$ dan terendah terdapat pada perlakuan direndam selama 120 menit (L2) sebesar $7.86 \mathrm{~cm}$. Tinggi tunas tertinggi terdapat pada perlakuan PVS1 (J1) sebesar $9.32 \mathrm{~cm}$ dan terendah terdapat pada perlakuan PVS3 (J3) sebesar $8.46 \mathrm{~cm}$.

Pertumbuhan embrio selama proses perkecambahan bergantung pada persiapan bahan makanan yang berada di dalam endosperm, sehingga untuk memenuhi keperluan kelangsungan hidup embrio ini, maka terjadilah penguraian secara enzimatik yaitu terjadi perubahan pati menjadi gula yang selanjutnya ditranslokasikan ke embrio sebagai sumber energi sehingga biji berkecambah. Disamping itu, semakin lama biji direndam juga tidak lagi menaikkan kemampuan perkecambahan benih (Abidin, 1993).

Disamping ini proses perkecambahan memanfaatkan cadangan makanan yang ada di dalam biji, sehingga berkolerasi positif dengan banyaknya cadangan makanan yang ada di dalam biji, berkaitan juga dengan ukuran biji manggis, jadi berdasarkan hal tersebut, wajar bila tinggi tunas, panjang akar dan bobot kering kecambah tertinggi terdapat pada perlakuan tanpa daging buah dan diperngaruhi dengan ukuran biji yang berkecambah lebih awal. Lalu dipengaruhi juga oleh faktor-faktor internal dan eksternal. 
Tabel 1.Tinggi Tunas (cm) efek penyimpanan secara kriopreservasi pada jenis dan lama perendaman krioprotektan dengan perbedaan kondisi biji terhadap pertumbuhan benih manggis.

\begin{tabular}{|c|c|c|c|c|c|c|c|}
\hline \multirow{2}{*}{$\begin{array}{l}\text { Daging } \\
\text { Buah }\end{array}$} & \multirow{2}{*}{$\begin{array}{c}\text { Lama } \\
\text { Perendaman }\end{array}$} & \multicolumn{4}{|c|}{ Krioprotektan } & \multirow{2}{*}{$\begin{array}{c}\text { Rataan } \\
\text { D }\end{array}$} & \multirow{2}{*}{$\begin{array}{c}\text { Rataan } \\
\mathrm{T}\end{array}$} \\
\hline & & $\mathrm{J} 1$ & $\mathrm{~J} 2$ & $\mathrm{~J} 3$ & $\mathrm{~J} 4$ & & \\
\hline \multirow{3}{*}{ D1 } & L1 & 1.00 & 5.00 & 1.00 & 1.33 & \multirow{2}{*}{$1.71 \mathrm{bc}$} & \multirow{4}{*}{$4.98 \mathrm{a}$} \\
\hline & L2 & 1.67 & 5.33 & 1.33 & 1.00 & & \\
\hline & L3 & 2.00 & 5.67 & 2.00 & 2.33 & \multirow{2}{*}{$1.79 \mathrm{~b}$} & \\
\hline \multirow{3}{*}{$\mathrm{D} 2$} & L1 & 1.33 & 2.00 & 1.00 & 1.00 & & \\
\hline & L2 & 1.00 & 2.00 & 1.00 & 1.00 & \multirow{2}{*}{$2.08 \mathrm{a}$} & \multirow[t]{2}{*}{$2.49 \mathrm{~b}$} \\
\hline & L3 & 1.00 & 1.67 & 1.00 & 1.00 & & \\
\hline & aan $\mathrm{J}$ & $1.33 \mathrm{~b}$ & $3.61 \mathrm{a}$ & $1.22 \mathrm{~cd}$ & $1.28 \mathrm{c}$ & & \\
\hline
\end{tabular}

Tabel 2.Jumlah Tunas (buah) efek penyimpanan secara kriopreservasi pada jenis dan lama perendaman krioprotektan dengan perbedaan kondisi biji terhadap viabilitas benih manggis.

\begin{tabular}{|c|c|c|c|c|c|c|c|}
\hline \multirow{2}{*}{$\begin{array}{c}\text { Daging } \\
\text { Buah }\end{array}$} & \multirow{2}{*}{$\begin{array}{c}\text { Lama } \\
\text { Perendaman }\end{array}$} & \multicolumn{4}{|c|}{ Krioprotektan } & \multirow{2}{*}{$\begin{array}{c}\text { Rataan } \\
\text { D }\end{array}$} & \multirow{2}{*}{$\begin{array}{c}\text { Rataan } \\
\mathrm{T}\end{array}$} \\
\hline & & $\overline{\mathrm{J} 1}$ & $\mathrm{~J} 2$ & $\mathrm{~J} 3$ & $\overline{\mathrm{J} 4}$ & & \\
\hline \multirow{3}{*}{ D1 } & $\mathrm{L} 1$ & 9.60 & 8.99 & 8.63 & 7.88 & \multirow{2}{*}{9.27} & \multirow{4}{*}{9.20} \\
\hline & L2 & 8.97 & 8.32 & 8.17 & 6.87 & & \\
\hline & L3 & 11.05 & 8.99 & 11.33 & 11.65 & \multirow{2}{*}{7.86} & \\
\hline \multirow{3}{*}{ D2 } & $\mathrm{L} 1$ & 10.03 & 10.48 & 9.00 & 9.57 & & \\
\hline & L2 & 6.83 & 9.30 & 4.93 & 9.47 & \multirow{2}{*}{9.55} & \multirow[t]{2}{*}{8.58} \\
\hline & L3 & 9.43 & 6.65 & 8.70 & 8.60 & & \\
\hline & aan J & 9.32 & 8.79 & 8.46 & 9.01 & & \\
\hline
\end{tabular}

Keterangan : Angka-angka yang diikuti huruf yang berbeda pada kolom atau baris yang sama menunjukkan berbeda nyata menurut Uji Jarak Berganda Duncan pada taraf $\alpha=5 \%$ 


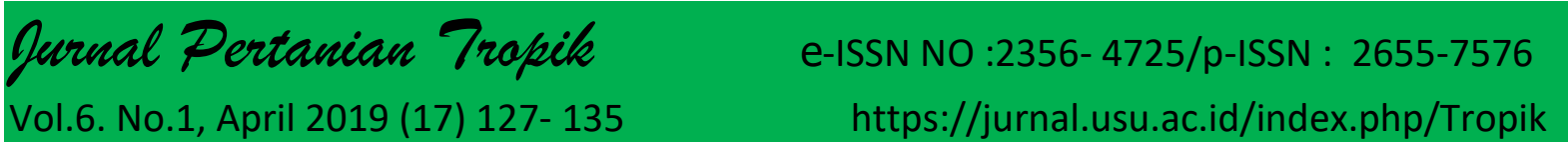

Tabel 2 menunjukkan bahwa jumlah tunas tertinggi terdapat $\cdots$ d perlakuan tanpa daging buah (D1) ؛ 130 2.47 buah dan terendah terdapat pada perlakuan daging buah (D2) sebesar 1.25 buah. Perlakuan tanpa daging buah (D1) berbeda nyata dengan perlakuan daging buah (D2).

Tabel 2 menunjukkan bahwa jumlah tunas tertinggi terdapat pada perlakuan direndam selama 180 menit (L3) sebesar 2.08 buah dan terendah terdapat pada perlakuan direndam selama 60 menit (L1) sebesar 1.71 buah. Perlakuan direndam selama 180 menit (L3) berbeda nyata dengan perlakuan direndam selama 60 menit (L1) dan direndam selama 120 menit (L2).

Tabel 2 menunjukkan bahwa jumlah tunas tertinggi terdapat pada perlakuan PVS2 (J2) sebesar 3.61 buah dan terendah terdapat pada perlakuan PVS3 (J3) sebesar 1.22 buah. Perlakuan
PVS2 (J2) berbeda nyata dengan perlakuan PVS1 (J1), PVS3 (J3) dan PVS4 (J4).

Perlakuan yang menggunakan nitrogen cair dapat menunda proses perkecambahan setelah penanaman dilakukan pada kondisi suhu yang kurang optimum yaitu suhu nitrogen cair yang sangat rendah yakni $-196^{\circ} \mathrm{C}$. Sutopo (1998) menyatakan daya kecambah benih memberikan kemampuan benih tumbuh normal menjadi tanaman yang wajar dalam keadaan biofisik lapangan yang serba optimum.

Pada perlakuan menggunakan nitrogen cair tertinggi adalah hanya menggunakan krioprotektan dan penggunaan laju pendinginan kurang optimal sebagai faktor yang mempengaruhi keberhasilan dari kriopreservasi.

Panjang Akar (cm)

Tabel 3.Panjang Akar $(\mathrm{cm})$ efek penyimpanan secara kriopreservasi pada jenis dan lama perendaman krioprotektan dengan perbedaan kondisi biji terhadap viabilitas benih manggis.

\begin{tabular}{|c|c|c|c|c|c|c|c|}
\hline \multirow{2}{*}{$\begin{array}{c}\text { Daging } \\
\text { Buah }\end{array}$} & \multirow{2}{*}{$\begin{array}{c}\text { Lama } \\
\text { Perendaman }\end{array}$} & \multicolumn{4}{|c|}{ Krioprotektan } & \multirow{2}{*}{$\begin{array}{c}\text { Rataan } \\
\text { D }\end{array}$} & \multirow{2}{*}{$\begin{array}{c}\text { Rataan } \\
\mathrm{T}\end{array}$} \\
\hline & & $\mathrm{J} 1$ & $\mathrm{~J} 2$ & $\mathrm{~J} 3$ & $\mathrm{~J} 4$ & & \\
\hline \multirow{3}{*}{ D1 } & L1 & 4.50 & 4.06 & 2.50 & 2.95 & \multirow{2}{*}{$3.32 \mathrm{a}$} & \multirow{3}{*}{4.98} \\
\hline & L2 & 2.92 & 3.18 & 3.83 & 2.40 & & \\
\hline & L3 & 2.50 & 3.82 & 3.45 & 3.12 & \multirow{2}{*}{$2.80 \mathrm{c}$} & \\
\hline \multirow{3}{*}{ D2 } & L1 & 3.60 & 3.00 & 2.87 & 3.10 & & \multirow{3}{*}{2.49} \\
\hline & L2 & 2.60 & 3.50 & 1.63 & 2.30 & \multirow{2}{*}{$3.15 \mathrm{~b}$} & \\
\hline & L3 & 3.50 & 2.62 & 2.70 & 3.47 & & \\
\hline \multicolumn{2}{|c|}{ Rataan J } & $4.06 \mathrm{a}$ & $3.36 \mathrm{~b}$ & $2.83 \mathrm{~cd}$ & $2.89 \mathrm{c}$ & & \\
\hline
\end{tabular}

Keterangan : Angka-angka yang diikuti huruf yang berbeda pada kolom atau baris yang sama menunjukkan berbeda nyata menurut Uji Jarak Berganda Duncan pada taraf $\alpha=5 \%$ 


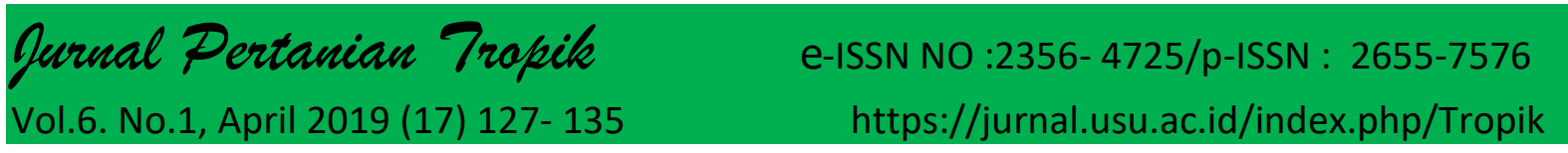

Tabel 3 menunjukkan bahwa panjang akar tertinggi terdapat pada perlakuan tanpa daging buah (D1) sebesar $3.27 \mathrm{~cm}$ dan terendah terdapat pada perlakuan daging buah (D2) sebesar 2.91 $\mathrm{cm}$.

Tabel 3 menunjukkan bahwa panjang akar tertinggi terdapat pada perlakuan direndam selama 60 menit (L1) sebesar $3.32 \mathrm{~cm}$ dan terendah terdapat pada perlakuan direndam selama 120 menit (L2) sebesar $2.80 \mathrm{~cm}$. Perlakuan direndam selama 60 menit (L1) berbeda nyata dengan perlakuan direndam selama 120 menit (L2) dan direndam selama 180 menit (L3).

Tabel 3 menunjukkan bahwa panjang akar tertinggi terdapat pada perlakuan PVS1 (J1) sebesar $4.06 \mathrm{~cm}$ dan terendah terdapat pada perlakuan PVS3 (J3) sebesar $2.89 \mathrm{~cm}$.Perlakuan PVS1 (J1) berbeda nyata dengan perlakuan PVS2 (J2), PVS3 (J3) dan PVS4 (J4).

Peranan akar dalam proses penyerapan hara sangat penting untuk perkembangan tunas tanaman. Pada awal perkecambahan hara yang digunakan untuk proses pertumbuhan berasal dari cadangan makanan dalam biji jadi semakin banyak cadangan makanan yang ada maka semakin banyak translokasi hara kepada akar dan tajuk tanaman. Peranan panjang akar awalnya berdasarkan cadangan makanan yang ada lalu untuk keberlanjutan tumbuh dibantu oleh hara yang ada di luar jadi ada pengaruh faktor eksternal dalam proses perpanjangan akar. Andjarikmawati et al (2005) menyatakan bahwa akar berperan dalam menyediakan unsur hara dan air yang diperlukan dalam metabolisme tanaman. Bobot kering kecambah juga berkaitan dengan jumlah kecambah normal yang didapat, jumlah tunas dan panjang akar, semakin banyak kecambah normal, jumlah tunas dan panjang akar maka makin besar pula bobot kering kecambah yang dihasilkan.

Penggunaan krioprotektan tidak memberikan pengaruh dengan pertumbuhan tanaman manggis. Jadi penggunaan krioprotektan tidak memberikan pengaruh kerusakan pada benih sehingga dapat digunakan perlakuan benih lainnya. Handayani (2004) menyatakan krioprotektan yang dapat menembus dinding sel (intraseluler) berfungsi memberikan perlindungan yang lebih baik pada laju pendinginan yang lambat, misalnya DMSO, etilen glikol (EG), dan gliserol, berdifusi menembus dan memasuki sel dan dapat dipakai sebagai aktivitas metabolisme oksidatif yang memasuki sel akan menggantikan sebagian air yang bebas dan mendesak ke luar elektrolit-elektrolit, menurunkan konsentrasi intraselular elektrolit-elektrolit tersebut dan mengurangi daya rusak terhadap sel tersebut. Penggunaan krioprotektan yang kurang optimum menyebabkan kerusakan pada benih semakin tinggi. Roostika dan Mariska (2003) menyatakan bahwa faktor yang mempengaruhi keberhasilan kriopreservasi adalah kecepatan pembekuan, jenis dan konsentrasi krioprotektan, suhu akhir pembekuan dan tipe dan keadaan fisiologis bahan yang akan disimpan. Jika pembekuan terlalu lambat maka sel terlalu terdehidrasi sehingga konsentrasi zat elektrolit dalam sel menjadi tinggi. Jika pembekuan terlalu cepat maka sel kurang mengalami dehidrasi sehingga terjadi formasi es intraselular yang bersifat letal. 


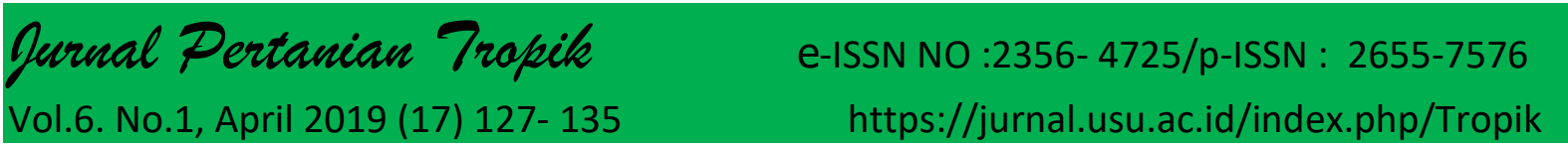

Bobot Kering Kecambah (g)

Tabel 4. Bobot kering kecambah $(\mathrm{cm})$ efek penyimpanan secara kriopreservasi pada jenis dan lama perendaman krioprotektan dengan perbedaan kondisi biji terhadap viabilitas benih manggis.

\begin{tabular}{|c|c|c|c|c|c|c|c|}
\hline \multirow{2}{*}{$\begin{array}{c}\text { Daging } \\
\text { Buah }\end{array}$} & \multirow{2}{*}{$\begin{array}{c}\text { Lama } \\
\text { Perendaman }\end{array}$} & \multicolumn{4}{|c|}{ Krioprotektan } & \multirow{2}{*}{$\begin{array}{c}\text { Rataan } \\
\text { D }\end{array}$} & \multirow{2}{*}{$\begin{array}{c}\text { Rataan } \\
\mathrm{T}\end{array}$} \\
\hline & & $\mathrm{J} 1$ & $\mathrm{~J} 2$ & $\mathrm{~J} 3$ & $\mathrm{~J} 4$ & & \\
\hline \multirow{3}{*}{ D1 } & L1 & 2.01 & 7.03 & 1.15 & 1.40 & \multirow{2}{*}{$2.31 \mathrm{~b}$} & \multirow{3}{*}{$3.42 \mathrm{a}$} \\
\hline & L2 & 1.52 & 5.35 & 1.75 & 0.66 & & \\
\hline & L3 & 3.58 & 9.94 & 3.25 & 3.37 & \multirow{2}{*}{$1.88 \mathrm{c}$} & \\
\hline \multirow{3}{*}{ D2 } & L1 & 1.56 & 3.07 & 1.21 & 1.03 & & \multirow{3}{*}{$1.47 \mathrm{~b}$} \\
\hline & L2 & 1.27 & 2.31 & 0.69 & 1.50 & \multirow{2}{*}{$3.14 \mathrm{a}$} & \\
\hline & L3 & 1.15 & 1.35 & 1.09 & 1.35 & & \\
\hline \multicolumn{2}{|c|}{ Rataan J } & $1.85 \mathrm{~b}$ & $4.84 \mathrm{a}$ & $1.52 \mathrm{c}$ & $1.55 \mathrm{c}$ & & \\
\hline
\end{tabular}

Keterangan : Angka-angka yang diikuti huruf yang berbeda pada kolom atau baris yang sama menunjukkan berbeda nyata menurut Uji Jarak Berganda Duncan pada taraf $\alpha=5 \%$

Tabel 4. menunjukkan bahwa bobot kering kecambah tertinggi terdapat pada perlakuan tanpa daging buah (D1) sebesar $3.42 \mathrm{~g}$ dan terendah terdapat pada perlakuan daging buah (D2) sebesar 1.47 g. Perlakuan tanpa daging buah (D1) berbeda nyata dengan perlakuan daging buah (D2).

Perlakuan perendaman memiliki bobot kering kecambah tertinggi terdapat pada perendam selama 180 menit (L3) sebesar $3.14 \mathrm{~g}$ dan terendah terdapat pada perlakuan direndam selama 120 menit (L2) sebesar 1.88 g. Perlakuan direndam selama 180 menit (L3) berbeda nyata dengan perlakuan direndam selama 60 menit (L1) dan direndam selama 120 menit (L2).

Tabel 4 menunjukkan bahwa bobot kering kecambah tertinggi terdapat pada perlakuan PVS2 (J2) sebesar $4.84 \mathrm{~g}$ dan terendah terdapat pada perlakuan PVS3 (J3) sebesar $1.52 \%$. Perlakuan PVS2 (J2) berbeda nyata dengan perlakuan PVS1 (J1), PVS3 (J3) dan PVS4
Berdasarkan hal ini bobot kering mencerminkan jaringan yang terbentuk setelah air di dalam jaringan tanaman dikeluarkan. Prawiranata, Haran dan Tjondronegoro (1991) menyatakan bahwa berat kering tanaman mencerminkan jaringan yang terbentuk setelah air dikeluarkan dan sekaligus cerminan dari komposisi hara yang ada pada tanaman tersebut. Tersedianya hara yang cukup akan mendorong pertumbuhan dan perkembangan tanaman lebih baik sehingga meningkatkan bahan kering tanaman yang dibentuk. Selain itu bahan kering tanaman merupakan hasil penumpukan fotosintat pada sel dan jaringan tanaman, dan hal ini ditentukan oleh ketersediaan hara pada media tanam (Jumin, 1987).

Perlakuan yang menggunakan nitrogen cair dapat menunda proses perkecambahan setelah penanaman dilakukan pada kondisi suhu yang kurang optimum yaitu suhu nitrogen cair yang sangat rendah yakni $-196^{\circ} \mathrm{C}$. 
Sutopo (1998) menyatakan daya kecambah benih memberikan kemampuan benih tumbuh normal menjadi tanaman yang wajar dalam keadaan biofisik lapangan yang serba optimum.

Pada perlakuan menggunakan nitrogen cair tertinggi adalah hanya menggunakan krioprotektan dan penggunaan laju pendinginan kurang optimal sebagai faktor yang mempengaruhi keberhasilan dari kriopreservasi. Rataan terendah terdapat pada perlakuan mennguakan krioprotektan PVS3 karena didapatkan hasil yang rendah sehingga penggunaan krioprotektan PVS3 juga menunjukkan hasil kecambah normal yang rendah yang berhubungan dengan tinggi tunas, panjang akar dan bobot kering kecambah. Kondisi laju pendinginan awal yang kurang optimum bisa merusak sel yang akan dilakukan pada tahapan perlakuan sebelum menggunakan nitrogen cair. Khoirinaya (2011) menyatakan laju pendinginan yang lambat menyebabkan tingginya peluang terbentuknya kristal es yang bersifat letal bagi sel. Terbentuknya kristal es intraselular dapat menyebabkan kerusakan membran, organel sel dan hilangnya kemampuan embrio untuk tumbuh setelah proses pembekuan. Kunci keberhasilan tidak terlepas dari pengoptimalan masing-masing tahap prosedur yang digunakan dalam hubungannya dengan ukuran, permeabilitas, dan sifat fisiologi awal sel tersebutsehingga dapat mempertahankan sel.

\section{SIMPULAN}

Daging buah tertinggi terdapat pada perlakuan tanpa daging buah (D1) pada pengamatan tinggi tunas $(\mathrm{cm})$, jumlah tunas (buah) panjang akar $(\mathrm{cm})$ dan bobot kering kecambah $(\mathrm{g})$.
Pemberian krioprotektan tertinggi terdapat pada perlakuan PVS1 pada pengamatan tinggi tunas $(\mathrm{cm})$ dan panjang akar (cm), perlakuan PVS2 pada pengamatan jumlah tunas (buah) dan bobot kering kecambah $(\mathrm{g})$.

Lama perendaman tertinggi terdapat pada perlakuan 180 menit (L3) pada pengamatan bobot kering kecambah $(\mathrm{g})$, tinggi tunas $(\mathrm{cm})$ dan Jumlah tunas (buah). Perlakuan 60 menit (L1) pada pengamatan panjang akar $(\mathrm{cm})$.

\section{UCAPAN TERIMA KASIH}

Terima Kasih penulis ucapkan kepada SIMLITABMAS dan DRPM RISTEKDIKTI dalam bantuan biaya penelitian ini, semoga bermanfaat bagi peneliti dan Institusi tempat saya mengabdi.

\section{DAFTAR PUSTAKA}

Abidin, Z. 1993. Dasar Dasar Pengetahuan Tentang Zat Pengatur Tumbuh. Angkasa Bandung. Jakarta.

Andjarikmawati,D.W.,Mudyantini,W.,Mars usi. 2005. Perkecambahan dan Pertumbuhan Delima Putih (Punica granatum L) Dengan Perlakuan Asam Indol Asetat dan asam Giberelat. J. Biosmart 7(2): 91-94. Fitriyatmi, I. 1996. Pengaruh Suhu Rendah Terhadap Viabilitas Benih Jagung (Zea mays L.) Kedelai (Glycine max (L) Merr.) Rambutan (Nephelium lappaceum) dan Matoa (Pometia pinnata) Setelah Pembekuan Dalam Nitrogen Cair. Skripsi. Program Studi Budidaya Pertanian. Fakultas Pertanian. Institut Pertanian Bogor. Bogor. Hal : 2-15.

Handayani, S. 2004. Penggunaan Dimetilsulfoksida (DMSO) dan Gliserol 5, 10 dan $15 \%$ Terhadap Kualitas Sperma Pada Kriopreservasi Semen Ikan Batak (Tor soro). Skripsi. Program Studi 
Teknologi dan Manajemen Akuakultur. Departemen Budidaya Perairan. Fakultas Perikanan dan Ilmu Kelautan. Institut Pertanian Bogor. Bogor. Hal : 9-10.

Jumin, A.,B.1987. Dasar Dasar Agronomi. Rajawali Press. Jakarta.

Khoirinaya, C. 2011. Viabilitas Embrio

Mencit (Mus musculus albinus)

Setelah Kriopreservasi Dengan Vitrifikasi Ganda Pada Tahap Perkembangan Zigot dan

Dilanjutkan Pada Tahap Blastosis.

Skripsi. Fakultas Kedokteran Hewan. Institut Pertanian Bogor. Bogor. Hal : 6-7.

Ihsan, F dan Sukarmin. 2011. Teknik Pengujian Pembelahan Biji Terhadap Efektivitas Perbanyakan Manggis (Garcinia mangostana L) Melalui Biji. Bul Teknik Pertanian 16(2) : $58-60$.

Novita, D. D. 2011. Penentuan Pola Peningkatan Kekerasan Kulit manggis Selama Penyimpanan Dingin Dengan Metode NIR Spectroscopy.Thesis. Sekolah Pasca Sarjana Institut Pertanian Bogor.

Prawiranata, W. S., Haran, P., Tjondronegoro.1991. Dasar Dasar Fisiologi Tumbuhan Jilid II. Departemen Botani Fakultas Pertanian. IPB. Bogor.

Roostika, I. T dan I. Mariska. 2003. PemanfaatanTeknik Kriopreservasi
Dalam Penyimpanan Plasma Nutfah Tanaman. Bul. Plasma Nutfah. 9(2).

Roostika, I. T., I. Mariska dan N. Sunarlim. 2004.

Penyimpanan Ubi Kayu

(Manihot utilisima) Secara Kriopreservasi Dengan Teknik Vitrivikasi. J.

Bioteknologi Pertanian. 9(1):8-15.

Sutopo, L. 1998. Teknologi Benih. PT Raja Grafindo. Jakarta.

Sumiasih, I. H. 2011. Studi Perubahan kualitas Pascapanen Buah Manggis (Garcinia mangostana L) Pada Beberapa Stadia Kematangan Suhu Simpan. Thesis. Sekolah Pasca Sarjana Institut Pertanian Bogor.

Whidhiasih, R. N. 2012. Pengembangan Model Klasifikasi Kematangan Buah Manggis Berdasarkan Warna Menggunakan Fuzzy Neural Network. Thesis. Sekolah Pasca Sarjana Institut Pertanian Bogor.

Widiastuti, A.,Sobir.,Suhartanto, M.R.2013. Analisis Keragaman Genetik Manggis (Garcinia mangostana L) Diiradiasi Dengan Sinar Gamma Berdasarkan Penanda ISSR. J. Bioteknologi Vol 10 (1): 15-22.

Windiastika, G. 2013. Konservasi Plasma Nutfah Tanaman Dengan Teknik Kriopreservasi. Balai Besar Perbenihan dan Proteksi Tanaman Perkebunan. Surabaya. 